\title{
Substance and Drug Abuse in The Bahamas and the Caribbean, 1970-2017: A Bibliography
}

\author{
Antoinette P. Pinder-Darling \\ Virginia C. F. Ballance \\ University of The Bahamas ${ }^{1}$
}

\begin{abstract}
An objective for the compilation of this bibliography is to provide a list of resources that address substance and drug abuse in The Bahamas and the wider Caribbean from its beginnings in the 1980 s to present day by medical professionals, academics, policy makers and government officials. Therefore, research was conducted to compile as full a bibliographic listing of resources as possible, including links for digital documents. This bibliography does not include everything written about drug and substance abuse in The Bahamas and Caribbean, but it is a guide and starting point for researchers.
\end{abstract}

\section{Introduction}

In 2011 the Organization of American States (OAS) initiated a pan-Caribbean project focusing on drug demand reduction in the university environment and the wider community. The College of The Bahamas participated in the initiative, known as "A Caribbean University Interdisciplinary and Integrated Drug Demand Reduction Proposal," by implementing drug-related course content throughout the curriculum and by implementing drug-use prevention activities on its campuses and in the wider community. A secondary objective was to encourage scholarly research on drug issues.

To facilitate the research objective, a bibliography of resources addressing the issues and struggles of substance and drug abuse in The Bahamas and the wider Caribbean region was deemed to be a useful outcome of the project. Drug and substance abuse in the region is a plaguing reality, touching everyone, from the public to healthcare providers to policy makers. It is important to make literature available to researchers for a more systematic study of the topic both locally and throughout the region.

Therefore, a literature review was conducted to compile a bibliographic listing of resources, providing a complete reference citation for each item as well as annotating some of the studies with a brief abstract to help potential users evaluate the documents' contents. For all electronically available materials a linking URL or DOI (digital object identifier) has been provided to ease retrieval of the document.

Compiling a bibliography of Bahamian and Caribbean resources is fraught with problems. In The Bahamas there is no national library with the mandate to collect all publications written by Bahamians, documents with

${ }^{1}$ Antoinette P. Pinder-Darling and Virginia C. F. Ballance, University Libraries, University of The Bahamas E-mail: antoinette.pinder@ub.edu.bs

APA reference: Pinder-Darling, A. P., \& Ballance, V. C. F. (2017). Substance and drug abuse in The Bahamas and the Caribbean, 1970-2017: A bibliography. International Journal of Bahamian Studies, 23, 67-77. https://doi.org/10.15362/ijbs.v23i0.284

(C) Pinder-Darling \& Ballance, 2017. Journal compilation @ International Journal of Bahamian Studies, 2017 
significant content about The Bahamas or items published in the country. There is no system of obligatory legal deposit of all publications produced locally, nor is there a unified government publications department responsible for the dissemination of all official publications. In addition, few, if any, publications emanating from government departments are supplied with an ISBN (International Standard Book Number) which would assist with bibliographic control of publications-ensuring that they are catalogued and recorded in bibliographic databases. Further complicating the effort is that in this age of in-house desktop and web-publishing, authors and publishers can produce books, conference proceedings, reports, and other publications with relative ease, but such publications are produced in small numbers, are difficult to locate or may be produced in multiple versions. As a result, researchers compiling bibliographies must scour traditional and non-traditional sources to find all published materials on a topic.

To produce as complete a resource list as possible, we searched Google, Google Scholar and EbscoHost databases using the terms "drug abuse," "substance abuse," and "drug control" to retrieve articles published in scholarly journals. We sought resources relating to The Bahamas and the Caribbean in general. We also searched for World Health Organization, Pan American Health Organization and other international organization documents using the World Health Organization IRIS database. The WorldCat database provided access to a wide range of library online catalogues where we found many monographs and journal articles.

This bibliography does not include all materials written about drug use and abuse of other substances within The Bahamas and the Caribbean but should be a guide and starting point for researchers and students alike to access current and vetted resources.
Many more references to books, reports and articles have been added to the original bibliography prepared for the Inter-American Drug Abuse Control Commission (whose acronym is CICAD) in 2015. Items which were deemed to be valuable and important contributions to the literature were digitized and added to the Digital Library of the Caribbean, thereby ensuring access to the document in years to come.

All entries in the bibliography are in the American Psychological Association or APA $6^{\text {th }}$ edition style and include the updated format for digital object identifiers.

\section{BAHAMAS}

Allen, D. (Ed.). (1987). The cocaine crisis. New York: Plenum.

This early volume documents the devastating effects of crack, then a new cocaine preparation, and its extraordinary addicting properties. The Bahamian experience with crack provided an early warning about the extreme personal and social dangers of this drug. The book includes the proceedings of the first International Drug Symposium on Cocaine held in 1985 as well as papers presented at the symposium and articles published first in scholarly journals.

Allen, D. F., \& Jekel, J. F., (1991). Crack: The broken promise. Basingstoke, Hampshire, Eng.: Macmillan Academic and Professional.

Anderson, T. J. (2003). Curriculum matters: A grounded analysis of drug education in public primary and junior high schools in The Bahamas. (Unpublished Master's thesis). Acadia University, Wolfville, Nova Scotia.

Archer, C. (2003). Bahamian alcoholism (1955-2003) and other drug abuse (19682003): A works compilation. Nassau, Bahamas: Colmar.

Archer, C. B. (1981). The handbook on alcoholism in The Bahamas. Nassau, 
Bahamas: Colmar.

As far back as 1975, many of physicians in The Bahamas were becoming aware that there were chemicals being abused other than alcohol, marijuana, or prescription drugs. Heroin, PCP, but more significantly cocaine, were being used. In 1982, cocaine began to make its presence known in The Bahamas and by 1983 a full-blown epidemic had arrived.

Bahamas Drug Information System. (2003). Annual national report, 2001. Nassau, Bahamas: Author. http://www.unodc.org/pdf/barbados/baha mas_drug_report_2001.pdf

Bahamas. National Anti-Drug Secretariat. (2010). Bahamas drug information system annual report, 2009. Nassau, Bahamas: Ministry of National Security. Retrieved from http://dloc.com/I/AA00059019/00001

The annual reports of Bahamas Drug Information System provide information on the drug consumption in The Bahamas and an overview of the drug situation and trends including a synopsis of illicit supply and control of drugs, drug use and abuse, treatment and rehabilitation, morbidity and mortality, and specific drugs which include cocaine, marijuana, and other drugs.

Bahamas. Commission of Inquiry. (1984). Report of the Commission of Inquiry: appointed to inquire into the illegal use of The Bahamas for the transshipment of dangerous drugs destined for the United States of America, November 1983December 1984. Nassau, Bahamas: Government Printing.

In 1983 of a Commission of Inquiry was struck to investigate the drug trade and official corruption in The Bahamas. As a result of the Inquiry, five government ministers either resigned or were dismissed.

Bahamas. Ministry of Foreign Affairs.
(1992). Bahamas narcotics control report, 1991. Nassau: Author. (23 p.)

Bahamas. National Anti-Drug Secretariat. (2004). National anti-drug plan of the Commonwealth of The Bahamas, 20042009. Nassau, Bahamas: Author.

This 152-page resource includes community drug use survey results along as well as bibliographical references and appendices.

Bahamas. National Anti-Drug Secretariat. (2012). National anti-drug strategy of the Commonwealth of The Bahamas, 20122016. Nassau, Bahamas: Author. http://www.cicad.oas.org/fortalecimiento_i nstitucional/planesnacionales/Bahamas_20 12_2016.pdf (54 p., bibliography)

Bahamas. National-Anti Drug Secretariat. (2016). The drug situation in The Bahamas, 2015. Nassau, Bahamas: National Drugs Observatory.

https://www.bahamas.gov.bs/wps/wcm/co nnect/156c8ff0-3c24-4c8e-86e2-

8c053800ee66/Drug+Situation+Report+201

5.pdf?MOD=AJPERES\&CONVERT_TO=url\&C

ACHEID=156c8ff0-3c24-4c8e-86e2-

8c053800ee66 (102 p., bibliography)

The National Anti-Drug Secretariat will issue annual reports going forward from 2015.

Bahamas. National Anti-Drug Secretariat. (2017). The Commonwealth of The Bahamas national anti-drug strategy, 2017-2021: Refocusing our attention on those most vulnerable in the world drug problem. Nassau, Bahamas: Ministry of National Security. https://www.bahamas.gov.bs/wps/wcm/co nnect/b1197f59-5900-4226-94a9-

af511351b1bf/National+anti-

Drug+Strategy+2017-

2021.pdf?MOD=AJPERES\&CONVERT_TO=url \&CACHEID=b1197f59-5900-4226-94a9af511351b1bf 
National Anti-Drug Strategy for 2017-2021 is the framework in which action will be taken over the next five years. It represents a shift in focus from treating the drug problem as a criminal justice issue to a public health approach, a key objective being to educate the nation's youth about all aspects of the issue, empowering them to make informed choices about drug use.

Bahamas National Drug Council. (2003). Bahamas secondary school drug prevalence survey, 2003. Nassau, Bahamas: Author. http://www.bahamas.gov.bs/wps/wcm/co nnect/f8e0ec2c-f75f-4888-bf19-

9164fc9ead57/2002+School+Drug+Survey+R eport+No+Title+Page+\%281\%29.pdf?MOD= AJPERES\&CONVERT_TO $=u r \mid \& C A C H E I D=f 8 e 0$ ec2c-f75f-4888-bf19-9164fc9ead57 (88 p. includes survey instrument).

Bahamas National Drug Council. (2008). Bahamas secondary school drug prevalence survey, 2008: Executive summary. Nassau, Bahamas: Author. http://www.bahamas.gov.bs/wps/wcm/co nnect/71959fc5-c93c-4ae2-9ffo-

6d8a10706f99/2008+School+Survey+Executi ve+Summary.pdf?MOD=AJPERES\&CONVERT _TO=url\&CACHEID=71959fc5-c93c-4ae29ff0-6d8a10706f99

Bahamas National Anti-Drug Secretariat. (2012). Bahamas secondary school drug prevalence survey, 2012: Executive summary. Nassau, Bahamas: Author. (31 p.) http://www.bahamas.gov.bs/wps/wcm/co nnect/71959fc5-c93c-4ae2-9ffo6d8a10706f99/2008+School+Survey+Executi ve+Summary.pdf?MOD=AJPERES\&CONVERT _TO=url\&CACHEID=71959fc5-c93c-4ae29ff0-6d8a10706f99

National Drug Council/Anti-Drug Secretariat reports of three surveys conducted in 2002, 2008 and 2011 of substance abuse by secondary school population. The National
Anti-Drug Secretariat website is a good resource for statistics and reports.

Bahamas. National Task Force against Drugs. (1984). Report of the National Task Force on drug abuse in The Bahamas. Nassau,

Bahamas: Author.

The report emphasizes that The Bahamas faces a severe drug problem, one that is more enculturated rather than epidemic.

Christie, K., Clarke, N., \& Frankson, M. (2013). A survey of patients with substance use disorders at government treatment facilities in The Bahamas. West Indian Medical Journal, 62(7), 610-614. https://doi.org/10.7727/wimj.2012.250

To determine the sociodemographic information and characteristics of patients aged 18-60 years diagnosed with substance use disorders presenting at the three Government treatment facilities. To determine the prevalence rates of alcohol, cannabis, cocaine and poly-substance use disorders in patients presenting to government treatment facilities.

Clarke, N. (1987). Drug abuse, 1975-1985:

Clinical perspectives of the Bahamian experience of illegal substances. In D. Allen (Ed.), The cocaine crisis (pp. 133-137). New York: Plenum.

Clarke, N., \& Neville, M. (1986, July). Drug abuse in The Bahamas. Bulletin of the Royal College of Psychiatrists, 10, 176-177. https://doi.org/ 10.1192/pb.10.7.176

Neville, M., \& Clark, N. (1985). Drug abuse in The Bahamas. Journal of Substance Abuse Treatment, 2(3), 195-197. https://doi.org/10.1016/07405472(85)90053-4

The Bahamas has not always had a drug problem but there seems to be a significant change in this area over the years. There is a widespread increase in the quantity of drugs 
smoked by individual users. These three articles examine the concept of "free-basing" and its introduction to the country during the late 1970 s and early 1980s.

Davis, D., Ferguson, V., Carey, J., \& Ferguson, E. W. (2008). Ethanol in fatal road traffic accidents: The prevalence of ethanol in fatal road traffic accidents in The Bahamas: The need for a controlled study. The College of The Bahamas Research Journal, 13, 40-47. https://doi.org/10.15362/ijbs.v13i0.59

This paper provides a retrospective analysis of the involvement of ethanol in road traffic fatalities for 2000-2002 in The Bahamas. In the three-year period covered by this study 185 traffic fatalities were recorded, post mortem blood samples from 139 decedents were analyzed for blood alcohol concentration.

Dean-Patterson, S. (1987). Cocaine and the Bahamian woman: Treatment issues. In D. Allen (Ed.), The cocaine crisis (pp. 145-159). New York: Plenum.

This resource discusses the high-risk behaviours and treatments associated with cocaine use among Bahamian women.

Fielding, W. J., \& Plumridge, S. (2010). The association between pet care and deviant household behaviors in an Afro-Caribbean, college student community in New Providence, The Bahamas. Anthrozoos, 23(1), 69-78.

https://doi.org/10.2752/175303710X12627 079939224

The link between domestic violence and drug use, both at the household and personal levels, other deviant behaviors and pet care was observed through survey responses from 641 college students in New Providence, The Bahamas.

Gawin, F. H., Allen, D., \& Humblestone, B.
(1989). Outpatient treatment of 'crack' cocaine smoking with flupenthixol

decanoate: A preliminary report. Archives of General Psychiatry, 46(4), 322-325. https://doi.org/10.1001/archpsyc.1989.018 10040028005

Gomez, M. P., Bain, R. M., Major, C., Gray, H., \& Read, S. E. (1996). Characteristics of HIV-infected pregnant women in The Bahamas. JAIDS: Journal of Acquired Immune Deficiency Syndrome, 12(4), 400405. https://doi.org/10.1097/00042560199608010-00011

Gomez, M. P., Kimball, A. M., Orlander, H., Bain, R. M., Fisher, L. D., \& Holmes, K. K. (2002). Epidemic crack cocaine use linked with epidemics of genital ulcer disease and heterosexual HIV infection in The Bahamas: Evidence of impact of prevention and control measures. Sexually Transmitted Diseases, 29(5), 259-264. https://doi.org/10.1097/00007435200205000-00002

Humblestone, B. G., \& Allen, D. F. (1987). The Bahamas and drug abuse. In D. Allen (Ed.), The cocaine crisis (pp. 119-124). New York: Plenum.

The authors give an in-depth account of drug use and the drug user(s) struggle to stay sober. Users are smoking greater quantities of cocaine and marijuana and are leading to numerous mental health disorders.

Jekel, J. F., \& Allen, D. F. (1987). Trends in drug abuse in the mid-1980s. Yale Journal of Biology and Medicine, 60, 45-52. https://www.ncbi.nlm.nih.gov/pmc/articles /PMC2590226/ Includes bibliography.

This paper summarizes some of the causes of, and some of the health and social concerns from, the growing illicit drug problem in the 1980s. It suggests that two recent developments, the decentralization of much 
drug production and modification to chemical laboratories in homes, and the application of increasingly innovative marketing techniques, have brought us to a new and more hazardous era of drug abuse.

Jekel, J. F., Allen. D. F., Podlewski, H., \& Clarke, N. (1987). Epidemic freebase cocaine abuse: A case study from The Bahamas. In D. Allen (Ed.), The cocaine crisis (pp. 125132). New York: Plenum.

Jekel, J. F., Podlewski, H., Dean-Patterson, S., Allen, D. F., Clarke, N., \& Cartwright, P. (1986). Epidemic free-base cocaine abuse: Case study from The Bahamas. Lancet (London, England), 327(8479), 459-462. https://doi.org/10.1016/S01406736(86)92926-0 (this is a shorter version of the paper included in the volume)

Beginning in 1983, a sharp increase was noted in the number of new admissions for cocaine abuse to the only psychiatric hospital and to the primary outpatient clinic in The Bahamas. For the two facilities combined, the new admissions for cocaine abuse increased from none in 1982 to 69 in 1983, then to 523 in 1984.

Jekel, J. F., Allen. D. F., Clarke, N., Podlewski, H., Gray, H., \& Roberts, C. (1994) Nine years of the freebase cocaine epidemic in The Bahamas: Emergence of a new pattern. American Journal on Addictions, 3(1), 14-24. https://doi.org/10.1111/j.15210391.1994.tb00222.x

Nine years the beginning of the first reported nationwide epidemic of freebase (crack) cocaine abuse, which occurred in The Bahamas, a follow-up study was done to determine the pattern of the epidemic and the effectiveness of control measures.

Jones, G., \& Lafreniere, K. (2014). Exploring the role of school engagement in predicting resilience among Bahamian youth. Journal of Black Psychology, 40(1), 47-68. https://doi.org/10.1177/009579841246923 0

This study sought to identify the internal and external factors that are predictive of resilience in a sample of 103 urban Bahamian students. Ninth- and 11th-grade students from two local public schools completed surveys. Of special interest to this study was the relationship between school engagement and resilience. Although school engagement was significantly positively related to resilience, it was overshadowed by other factors when included in the resilience regression model. Relationships with parents and non-parental adults, involvement in meaningful activities, and self-efficacy were significant predictors of resilience in this sample of urban Bahamian students.

Kaljee, L., Wang, B., Deveaux, L., Lunn, S., Rolle, G., Villar, M. E., \& Stanton, B. (2016). Cross-sectional data on alcohol and marijuana use and sexual behaviour among male and female secondary school students in New Providence, The Bahamas. International Journal of Adolescent Medicine and Health, 28(2), 133-140. https://doi.org/10.1515/ijamh-2014-0079

While The Bahamas has significantly reduced poor reproductive health outcomes among adolescents and young adults, data indicate that youth are engaged in sexual risk behaviors. Substance use has been linked to increased risk for HIV and sexually transmitted infections in other contexts.

Manschreck, T. C., Laughery, J. A., Weisstein, C. C., Allen, D., Humblestone, B., Neville, M., Podlewski, H., \& Mitra, N. (1988). Characteristics of freebase cocaine psychosis. The Yale Journal of Biology and Medicine, 61(2), 115-122. https://www.ncbi.nlm.nih.gov/pmc/articles /PMC2590279/ 
Psychosis was present in 29 percent of cocaine-disordered patients hospitalized in 1985 during an epidemic of freebase cocaine abuse in The Bahamas. Record reviews revealed that a variety of psychotic phenomenological patterns were present. Prior major mental disorders and increased dosage of cocaine were more common among psychotic than non-psychotic patients. Violent behavior was common among cocaine patients, especially those with psychosis. We conclude that freebase cocaine psychosis is neither rare nor benign.

Manschreck, T. C., Allen, D. F., \& Neville, M. (1987). Freebase psychosis: Cases from a Bahamian epidemic of cocaine abuse. Comprehensive Psychiatry, 28(6), 555-564. https://doi.org/10.1016/0010440X(87)90022-8

McCartney, T., \& Neville, M. (1987). Treatment approaches to cocaine abuse and dependency in The Bahamas. In D. Allen (Ed.), The cocaine crisis (pp. 161-165). New York: Plenum.

Organization of American States. InterAmerican Drug Abuse Control Commission (CICAD). (2000). The Bahamas: Evaluation of progress in drug control, 1999-2000. Washington, DC: Author. http://www.cicad.oas.org/mem/reports/1/ Full_Eval/Bahamaseng_fin.pdf

Organization of American States. InterAmerican Drug Abuse Control Commission (CICAD). (2002). Evaluation of progress in drug control, 2001-2002. http://www.cicad.oas.org/mem/reports/2/ Full_Eval/Bahamas\%20-\%20eng.pdf

Organization of American States. InterAmerican Drug Abuse Control Commission (CICAD). (2004). Evaluation of progress in drug control, 2003-2004. http://www.cicad.oas.org/mem/reports/3/ Full_Eval/Bahamas\%20-\%20ENG.pdf

Organization of American States. InterAmerican Drug Abuse Control Commission (CICAD). (2006). Evaluation of progress in drug control, 2005-2006.

http://www.cicad.oas.org/mem/reports/4/ Full_Eval/Bahamas\%20-

\%20Fourth\%20Round\%20-\%20ENG.pdf

Organization of American States. InterAmerican Drug Abuse Control Commission (CICAD). (2010). Evaluation of progress in drug control, 2007-2009. http://www.cicad.oas.org/mem/reports/5/ Full_Eval/Bahamas\%20-\%205th\%20Rd\%20\%20ENG.pdf

Organization of American States. InterAmerican Drug Abuse Control Commission (CICAD). (2014). The Bahamas

(Commonwealth of) evaluation report on drug control, 2014.

http://cicad.oas.org/mem/reports/6/Full_E val/Bahamas\%20-

\%20Sixth\%20Evaluation\%20Round\%20\%20ENG.pdf

The national evaluation reports on drug control collect information on the implementation of OAS member states in the areas of institutional strengthening, demand reduction, supply reduction, control measures and international cooperation.

Plumridge, S. J., \& Fielding, W. J. (2009). Domestic violence in the homes of college students, New Providence, The Bahamas. The College of The Bahamas Research Journal, 15, 45-55. https://doi.org/10.15362/ijbs.v15i0.116

This paper identifies the link between a number of antisocial behaviors and domestic violence in 588 households of college students in Nassau, The Bahamas. The survey indicates that about $21 \%$ of college students 
could be living in homes with domestic violence. Further, domestic violence is associated with other deviant behaviours which may have adverse effects on household members and ultimately the welfare of the nation. The findings suggest that government policy regarding alcohol could be changed to reduce the participation of residents in behaviours linked to domestic violence.

Sherman-Peter, A. M. (2006). The Bahamas and international drug control, 1980-1994:

A perspective. Available at http://ufdc.ufl.edu/AA00054795/00001

Presentation made at The Bahamas Country Conference, June 8-9, 2006 at the University of the West Indies that provides a thorough overview of the history of drug control in The Bahamas.

Smart, R. G., \& Patterson, S. D. (1990). Comparison of alcohol, tobacco, and illicit drug use among students and delinquents in The Bahamas. Bulletin of the Pan American Health Organization, 24(1), 39-45. http://hist.library.paho.org/English/BUL/ev 24n1p39.pdf

Surveys of drug use were conducted among 4,767 junior and senior high school students in 1987 and 74 incarcerated delinquents in 1988 in The Bahamas. It was found that the majority of both groups reported having drunk alcohol, and substantial proportions had also smoked tobacco, although over twice as many delinquents as students had smoked. The results of the studies point to the need for increased drug education in The Bahamas and for efforts involving schools, churches, parents, the media, and Government.

\section{CARIBBEAN}

Cumberbatch, J. A., \& Duncan, N. C. (1990). Illegal drugs, U.S.A. policies and Caribbean responses: The road to disaster. http://ufdcimages.uflib.ufl.edu/CA/00/40/0
0/69/00001/PDF.pdf (40 p., bibliography)

Paper presented to the 15th annual conference of the Caribbean Studies Association, Trinidad, May, 23-26, 1990.

Day, M. (2011). Behavioural and HIV seroprevalence study of non-injection homeless and poor crack cocaine users in Saint Lucia. Castries, Saint Lucia: Caribbean Drug \& Alcohol Research Institute. http://www.hivgateway.com/files/8a55f42 83dc12ca32d8ab60881724760/Final_BSS_SL U_CrackUsers.pdf (38 p., bibliography)

The Caribbean region has the second highest burden of HIV/AIDS in the world, after Africa. While IV drug abuse is rare in the English speaking Caribbean, the use of crack cocaine is common. The role of crack cocaine in the Caribbean HIV/AIDS epidemic is not well documented.

Crack cocaine users may be an important, but under-recognized sub-population issue fuelling the Caribbean epidemic. United States-based studies are not generalisable to the Caribbean because American crack cocaine users report high-risk behaviours including sex with IV drug users. Thus, the risk of HIV infection among crack users in the Caribbean is likely to differ from the United States.

Hacker, M. A., Malta, M., Enriquez, M., \& Bastos, F. I. (2005). Human immunodeficiency virus, AIDS, and drug consumption in South America and the Caribbean: Epidemiological evidence and initiatives to curb the epidemic. Pan American Journal of Public Health $=$ Revista Panamericana de Salud Pública, 18(4-5), 303-313. https://doi.org/10.1590/S102049892005000900011

Insulza, J. M. (2013). The drug problem in the Americas: Legal and regulatory alternatives. Washington, DC: Organization 
of American States.

http://www.cicad.oas.org/drogas/elinform e/informeDrogas2013/alternativasLegales_E NG.pdf

Inter-American Drug Abuse Control Commission (CICAD). (2010). Comparative analysis of student drug use in Caribbean countries: A report on student drug use in 12 Caribbean countries. Washington, DC: Organization of American States. http://www.cicad.oas.org/Main/pubs/Stud entDrugUse-Caribbean2011.pdf (88 p. includes bibliography).

The Bahamas is included in this report.

Inter-American Drug Abuse Control Commission (CICAD). (2016). A report on student drug use in 13 Caribbean countries: Antigua and Barbuda, Bahamas, Barbados, Belize, Dominica, Grenada, Guyana, Haiti, Jamaica, St Kitts and Nevis, St Lucia, St Vincent and the Grenadines, Trinidad and Tobago. Washington, DC: Organization of American States. http://www.cicad.oas.org/oid/pubs/FINAL \%20SCHOOL\%20SURVEY\%20REPORT\%20201 6.pdf (130 p.)

Drug taking has been identified as one of the delinquent behaviors in which some adolescents engage. The use of drugs at an early age is a problem in itself, but it may also lead to or at least be associated with a set of other issues which may be detrimental to the health and well-being of young people. Research suggests that there is a relationship between academic performance and adolescent substance use. Students who use alcohol or illicit drugs have been shown to be at greater risk for performing poorly in school, and vice versa.

Inter-American Drug Abuse Control Commission. (2017). Hemispheric plan of action on drugs, 2016-2020: Approved at the CICAD sixtieth regular session, Nassau, The
Bahamas, November 2-4, 2016. Washington, DC: Organization of American States. http://cicad.oas.org/mem/Activities/PoA/P oA-Version_Final-ENG.pdf

Lee, E. E. (1984). The role of drugs in contemporary society. College Forum, 5, 1419. https://doi.org/10.15362/ijbs.v5i0.80

The Bahamas is adopting a drug using culture and many individuals are using drugs in their daily activities. Many persons are touched by the use of drugs and other chemicals.

Lee, M. G., \& Soyibo, K. (1999). Use of illicit drugs among high school students in Jamaica. Bulletin of World Health Organization, 77(3), 258-262.

http://www.who.int/bulletin/archives/77(3 258.pdf

Reported are the results of a survey to assess the prevalence of illicit drug use among highschool students in Jamaica.

Pan American Health Organization. (2009). Drug use epidemiology in Latin America and the Caribbean. Washington, DC: Author. http://iris.paho.org/xmlui/bitstream/handl e/123456789/2828/Drug\%20Use\%20Epidem iology\%20in\%20Latin\%20America\%20and\% 20the\%20Caribbean.pdf?sequence=1\&isAllo wed $=\mathbf{y}$

Pan American Health Organization. (2015). Regional status report on alcohol and health in the Americas. Washington, DC: Author. http://iris.paho.org/xmlui/bitstream/handl e/123456789/7670/9789275118559_Eng.pd f (80 p.)

Ruprah, I. J., Sierra, R., \& Sutton, H. (2017). Sex, violence, and drugs among Latin American and Caribbean adolescents: Do engaged parents make a difference? Children and Youth Services Review, 73, 4756.

https://doi.org/10.1016/j.childyouth.2016.1 0.001 
Singh, H., Maharaj, H. D., \& Shipp, M. (1991). Pattern of substance abuse among secondary school students in Trinidad and Tobago. Public Health, 105(6), 435-441. https://doi.org/10.1016/S00333506(05)80613-4

Singh, H., \& Mustapha, N. (1994). Some factors associated with substance abuse among secondary school students in Trinidad and Tobago. Journal of Drug Education, 24(1), 83-93. https://doi.org/10.2190/F3M1-8KAY-LBF3GDPQ

A questionnaire survey of 1,603 secondary school students, aged 14-18 years, was conducted in Trinidad and Tobago in 1988. Prevalence of alcohol use was $84 \%$, tobacco $35 \%$, marijuana $8 \%$ and cocaine $2 \%$. Alcohol was the substance most consistently used and students' first exposure to drinking alcohol was with family members.

World Bank. (2003). Caribbean youth development: Issues and policy directions. Washington, DC: The World Bank. http://documents.worldbank.org/curated/e n/499971468743177906/pdf/multiOpage.pd f

This report examines youth development in the Caribbean providing an overview of the risks Caribbean youth are facing, evidence of the protective and risk factors underlying the problems youth are facing, an estimation of the costs of risky youth behaviors, and an overview of the policy framework and the types of programs in place that target youth.

\section{INTERNATIONAL}

Blair, B., Tongue, E., Government of The Bahamas, World Federation of Mental Health, \& International Council on Alcohol and Addictions. (1974). Proceedings of the International Conference on the Prevention of Addictions in Developing Countries.
Lausanne, Switzerland: International Council of Alcohol and Addictions. (198 p.)

Proceedings of an international conference held in The Bahamas in 1974, includes papers presented by Bahamian and Caribbean physicians.

Cherry, A. L., Dillon, M. E., \& Rugh, D. (2002). Substance abuse: A global view. Westport, CT: Greenwood Publishing Group.

This book examines the deadly social issue of substance abuse through case studies highlighting 13 different countries from around the world. Using this resource, discover which countries keep the death rates from substance abuse low and how; how countries control the supply of drugs; and in which countries tactics seem to be failing. The answers vary, highlighting the lack of easy solutions, and encouraging readers to think critically.

Jernigan, D. H. (2001). Global status report: Alcohol and young people. Geneva, Switzerland: World Health Organization. http://apps.who.int/iris/bitstream/10665/6 6795/1/WHO_MSD_MSB_01.1.pdf

The World Health Organization (WHO) estimates that there are about 2 billion people worldwide consuming alcoholic beverages, and 76.3 million with diagnosed alcohol use disorders. From a public health perspective, the global burden of alcohol, both in terms of morbidity and mortality, is considerable; alcohol consumption causes $3.2 \%$ of deaths (1.8 million) and $4.0 \%$ of disability-adjusted life years (58.3 million). Overall, there are causal relationships between alcohol consumption and more than 60 types of disease and injury.

Obot, I. S., \& Saxena, S. (2005). Substance use among young people in urban environments. Geneva: World Health Organization. http://apps.who.int/iris/bitstream/10665/4 
3326/1/9241563060_eng.pdf

Rehm, J., Room, R., \& Taylor, B. (2006). The global burden of disease attributable to alcohol, tobacco and illicit drugs. Drug and Alcohol Review, 25(6), 503-513. https://dx.doi/10.1080/0959523060094445 3

The Comparative Risk Analysis conducted as part of the WHO's estimation of the Global Burden of Disease in 2000 included three categories of psychoactive substances: tobacco, alcohol and injectable illicit drugs (heroin, cocaine, amphetamines).

Room, R., Jernigan, D., Carlini-Marlatt, B., Gureje, O., Mäkelä, K., Marshall, M., ... \& Riley, L. (2002). Alcohol in developing societies: A public health approach. Helsiniki, Finland: Finnish Foundation for Alcohol Studies and World Health Organization. Executive summary available at this link:

http://www.who.int/substance_abuse/publ ications/en/APDSSummary.pdf

Singer, M. (2008). Drugs and development: the global impact of drug use and trafficking on social and economic development. International Journal of Drug Policy, 19(6), 467-478.

https://doi.org/10.1016/j.drugpo.2006.12.0 07

Locating development efforts within the context of globalism and global drug capitalism, this article examines the significant health and social impact both legal and illegal drugs have on international development efforts, including: interpersonal crime and community violence; (2) the corruption of public servants and the disintegration of social institutions; (3) the emergence of new or enhanced health problems; (4) the lowering of worker productivity; (5) the ensnarement of youth in drug distribution and away from productive education or employment; (6) the skewing of economies from drug production and money laundering. The case of The Bahamas is highlighted.

United Nations Office on Drugs and Crime. (2016). World drug report, 2016. http://www.unodc.org/wdr2016/

The World Drug Report, issued annual since 1997, provides a comprehensive overview of developments in the world's illicit drug markets by focusing on the production, trafficking and consumption of the main types of illicit drugs, along with the related health consequences of those drugs.

United National Office on Drug Control. (2016). Outcome document of the 2016 United Nations General Assembly Special Session on the World Drug Problem, New York, 19-21 April 2016: Our joint commitment to effectively addressing and countering the world drug problem. Vienna, Austria: UNODC. https://www.unodc.org/documents/postun gass2016/outcome/V1603301-E.pdf (32 p.)

World Health Organization. (2010). Atlas on substance use: Resources for the prevention and treatment of substance use disorders. Geneva, Switzerland: World Health Organization.

http://apps.who.int/iris/bitstream/10665/4 4455/1/9789241500616_eng.pdf

World Health Organization. (2014). Global status report: Alcohol and health. Geneva, Switzerland: Author. http://www.who.int/substance_abuse/publ ications/global_alcohol_report/msbgsruprof iles.pdf 